\title{
Energy Storage System Problem
}

National Cancer Institute

\section{Source}

National Cancer Institute. Energy Storage System Problem. NCI Thesaurus. Code C92050.

Problems related to the energy storage system (e.g. the rechargeable battery, charging system, or capacitor) and includes problems such as premature power source depletion and battery explosions. 